\title{
TRANSVERSAL COMPETENCIES OF INNOVATIVE ENTREPRENEURSHIP PROFESSIONALS IN LIFELONG EDUCATION
}

\author{
Svitlana Tolochko', Nataliia Bordiug ${ }^{2}$, Inna Knysh ${ }^{3}$
}

\begin{abstract}
For the effective development of Ukraine in the conditions of global changes (political, economic, social, educational) the priority should be transition to a new economy - knowledge economy. The basis of knowledge economy will be the professional development of specialists in innovative business structures through lifelong learning, in particular formation of their transversal competencies. These qualitatively new specialists will be able to ensure the transition of companies to innovative forms of organization of production activities. The purpose of the article is to reveal the importance of transversal competencies formation among specialists of innovative business structures in lifelong learning to ensure competitiveness of Ukrainian companies at the international level. Methodology. To achieve the goal, general scientific and special research methods were used: comparative analysis and generalization - to study the international experience of innovative business structures; synthesis of theoretical and empirical data - to characterize Ukrainian companies according to the innovation index; structural-functional and system analysis - to study the features of knowledge economy and form hard, soft and business skills. Results. In formation of business structures, Ukraine still uses traditional criteria, while in the world there are innovative approaches - companies "gazelles", clusters, etc. Characteristic features and problems of gazelle companies functioning are analyzed, in particular concerning the personnel component. It is proposed to consider successful enterprises as centers of new economic zones, around which related enterprises, promotion infrastructure, clusters should be purposefully built. It is determined that national economic competitiveness is associated with knowledge and innovation driven capital. Two approaches to the management of business structures are analyzed. The first is based on implementation of subject-subject relationships, development of innovative transversal competencies in order to expand managers' "breadth of management skills" through LLL-education. The second is the experience of innovative enterprises, where management is transformed into information management with its inherent impersonal post / non / management. Formation of the phenomenon of transversal competencies on the basis of LLL-education is analyzed. This is ensured by changes in hard skills, acquisition of new soft skills and integrated business skills, which contributes to the creation of a new generation of professionals. It is determined that business skills are integrated from soft skills, which accumulate intellectual property knowledge, investment and financial literacy, sales skills, presentations and business negotiations, event management, project management, people, their work and time, etc. Emphasis is placed on the importance of forming knowledge economy based on the intellectual potential of society, in which the main levers are the processes of accumulation and use of information and its transformation into knowledge, which depends on the economic progress of the country. It is determined that on the basis of formation of scientific and educational clusters, introduction of crowd technologies, crowdsourcing in education during life the professional development of experts of innovative business structures will be provided. Practical importance. The results of the research can be used in the creation of training programs, retraining, reskilling and changing types of work in the modern production space, which include provisions of knowledge economy for professional development of innovative business structures through lifelong learning. The basic postulates of research can be useful for managers whose companies implement innovative approaches to management, the latest technologies in production activities and promote mobility in retraining in accordance with sociel needs. Correlation/originality. Conclusions reached
\end{abstract}

\footnotetext{
Corresponding author:

${ }^{1}$ National University of Life and Environmental Sciences of Ukraine, Ukraine.

E-mail: svitlana-tsv@ukr.net

${ }^{2}$ Zhytomyr National Agroecological University, Ukraine.

E-mail: natali-21@ukr.net

${ }^{3}$ National Pedagogical Drahomanov University, Ukraine.

E-mail: knysh_sumy@ukr.net
} 
Vol. 6, No. 3, 2020

will help economists, politologists, social scientists and LLL learning educators to understand the importance of innovative concepts in development business structures and formation transverse competencies based on hard, soft and business skills.

Key words: Lifelong Learning education, innovative entrepreneurship structure, scientific and educational technologies, hard and soft skills, transversal competencies.

JEL Classification: A13, 125, O34

\section{Introduction}

Modern globalized world needs political, economic and social changes, but in close interdependence with education, because neglect of them will lead to regression of almost all spheres of human life. As for Ukraine itself, it is currently in a transitional (from industrial to informational) stage of its development, during which an individualized society was formed with an increased tendency to movement and displacement (nomadization). However, given the global changes taking place in the field of education, it is necessary to improve the quality of knowledge, skills development in lifelong learning. It is necessary to focus on international experience, innovative production technologies and their integration into national production and management strategy of the state as a whole and individual enterprises. Under such conditions, the value of lifelong learning (LLL - education) should be focused on stabilizing social tensions, optimizing the interaction between tradition and innovation (Voitovska, Tolochko, Bordyug, 2018). Thus, on the basis of basic education, a person will further decide when, how and where he will study, what quantity and quality of information he will need, that is he will be engaged in self-education and self-development.

Observing the growing role of uncontrolled forces and tendencies, which increase insecurity and uncertainty, deepen disorientation, limitations and helplessness, there is a desire to flee from reality, seeking refuge not in the real but in the virtual world, suppress those manifestations of the human spirit, which inspired social, economic and political transformations, are flattened. At the same time there was an opportunity for changes in all spheres of human life. Amidst virtualization, in particular, one of the interdisciplinary areas appears - "information management" as a "new era in management", based on two principles: subjectsubject relationships and subjectless post / non / management.

The urgency of this issue in scientific circles is determined by many factors, primarily the fact that in modern society there has been a change in management priorities - from production of goods (industrial society) through consumption (post-industrial) to the the society of production and service (information). Therefore, there is a good opportunity to review management mechanisms, focusing on:
1) interdisciplinary researches in lifelong learning, which allows specialists of innovative business organizations to acquire innovative business structures "breadth of skills" of formulation, formation, management and modernization of system competencies;

2) changes in management that have occurred recently from industrial (the limits of routine and monotonous movements and human actions) to a globalized society (technology and the limit of space-time restriction of a person) and led to a new interdisciplinary phenomenon - information management, i.e subjectless post / non / management.

Thanks to interdisciplinary researches, there is a need for new understanding, correction and improvement of lifelong learning for the professional development of professionals in innovative business structures capable of operating in today's and future society.

\section{Analysis of the activities of innovative business organizations}

American economist David Birch in the 80s of the twentieth century noted that jobs and innovative ideas in the economy are created by small and mediumsized businesses, which then grow and become large corporations. He called Gazelles enterprises and firms whose revenues have been increasing by at least $20 \%$ for at least four consecutive years and considered them to be points of economic growth. According to David Birch's calculations, dynamic companies account for a small share of the US economy (about 3\%), but account for 50 to $70 \%$ of GDP growth and employment (Birch, 1979).

Bruce Kirchhoff, developing a dynamic classification of firms by David Birch, proposed, in addition to growth index, to take into account the pace of innovation. Among other things Bruce Kirchhoff singled out four types of firms: "core"; "ambitious"; «glamorous»; "constrained" (Kirchhoff, 1994).

Bruce Kirchhoff traced the fate of 814,190 firms organized in $1977-1978$ - by 1984 there were 312,662 left. Studies have shown that $17 \%$ of highly innovative (gazelle firms) and 9\% of low-innovation firms achieve "spectacular" and "ambitious" statuses, respectively. However, the latter create four times more new jobs. These two groups of firms are real "creative destroyers". Luke Soete (1979) showed that innovation 
is related to the size of companies, and Raphael Kaplinsky (Kaplinsky, 1983) found that this relationship is dynamic in nature and depends on the phase of the business cycle. At the same time, David Birch's method alone is not enough to analyze companies in changing business conditions.

Fast gazelle firms are also called entrepreneurial, because their growth rates are largely determined not by markets, not by external conditions, but by internal factors, namely the innovative potential of both management and employees. Such firms influence the external socio-economic environment, set an example for other enterprises, and are a "trigger" mechanism when creating entire networks of interconnected and complementary structures - clusters.

The main condition for the formation of a cluster is to learn to respond to the competitive advantages of rivals by creating their own advantages. Unlike oligarchic groups, the firms of the "new economy" grew and prospered on their own. Introducing innovative researches and development, they continue to bring to market more and more new products, without attracting large infusions from investors, without access to cheap credit resources, without special attention from the state and so on. At the same time, there was their significant growth $-20-30 \%$ of profits annually, and now their average age is about 20 years. They are characterized by: exponential growth; conducting active research activities; focus on market success; important role of a leader in the company.

Unfortunately, the activities of innovative business structures operating in the world are almost not studied in domestic economics, and therefore there is a need to study the domestic business market in Ukraine and move to professional development and establishment of a new formation of entrepreneurs through lifelong learning, using opportunities for retraining and reskilling and changing types of work in the modern production space.

For this purpose, a special project Mind (2019) was created together with the open innovation platform Re:actor, company KPMG in Ukraine and with the support of Asbis, they presented the first in Ukraine "index of innovation of Ukrainian companies". It answers the questions of what innovations are currently being introduced by the biggest players in key sectors of the Ukrainian economy, how these innovations affect business, and whether today's leaders are ready for the challenges of the future. The study covered 50 companies in 10 sectors of the Ukrainian economy. Banks, metallurgy, energy, agro-industrial complex, transport, telecommunications, pharmaceutics, retail, consumer markets, real estate - according to KPMG experts in Ukraine, these industries will be most prone to change in the coming years. New players, modern business models, new rules that affect the distribution of forces in the market are already appearing there. In general, the index of innovation of Ukrainian companies showed that in each industry, even within the top 5 largest companies, there are both market drivers who change the rules of the game and outsiders - clumsy companies with many bureaucratic procedures that continue to benefit from past years and do not create almost nothing new. In only five of the ten industries did companies overcome the 75-point threshold, which allowed them to gain innovation status. This indicates low competition and ample opportunities for players who will be able to create new value and bring it to the market (Table 1).

Thus, the weakest point of Ukrainian companies was the use of traditional business models with the inclusion of new elements: a combination of classic and online forms. However, the share of large companies that dare to break their own established principles of making money remains quite low in Ukraine.

However, at the beginning of the XXI century introduction of ICT in all spheres of society has led to the invention, creation, production, dissemination, assimilation, accumulation, storage and disposal of information, as well as the appearance of a new phenomenon - neo-tribals, which led to the understanding of society as a complex new type of education - information (Knysh, 2018). That is why the leading and top priority are investments in human capacity building and the formation on this basis of society's intellectual potential - a qualitatively new "innovation enclave" of the world - diverse specialists of innovative business structures in lifelong learning.

\section{Formation of skills of specialists in innovative business structures}

In science, there is a transition to human-dimensional objects, which are complex systems (self-organized, nonlinear, unbalanced and open). It is also expressed in the possibility of independent choice of educational technologies, according to the individual needs of the psyche. Therefore, in the process of lifelong learning it is necessary to individually approach the choice of teaching methods, tools, technologies in order to stimulate the consciousness of the specialist to selfeducation, self-development and self-improvement, and forming motivation for professional development (Voitovska, Tolochko, 2019).

It should be noted that notable features of specialists of innovative business structures as leaders in traditional, pre-industrial societies were strong-willed and charismatic (full conviction in what he says and thinks, vision of prospects, ability to make others be interested in your ideas, ability to charge others with their positive energy, etc.) quality. A notable feature of such managers is the direct involvement in the production process. Instead, now, especially in information societies, there is a search for 
Vol. 6, No. 3, 2020

Table 1

Mind Innovation Index 2019

\begin{tabular}{|c|c|c|c|}
\hline $\begin{array}{l}\text { Name } \\
\text { of the company, } \\
\text { vote threshold }\end{array}$ & Characteristic of company's activity & Main innovation & $\begin{array}{l}\text { Evaluation of the innovation regarding } \\
\text { the future }\end{array}$ \\
\hline \multicolumn{4}{|c|}{ AGRO } \\
\hline $\begin{array}{l}\text { Agroprosperies, } \\
78 \text {, net profit } \\
2018 .: 16 \text { billion } \\
\text { UAN }\end{array}$ & $\begin{array}{l}\text { Provides goods and services for the } \\
\text { cultivation of cereals and oilseeds, } \\
\text { as well as storage and sale abroad. It } \\
\text { annually exports more than } 2.5 \text { million } \\
\text { tons of grain to North Africa, the Middle } \\
\text { East and Asia. }\end{array}$ & $\begin{array}{l}\text { Innovative methods of educating } \\
\text { farmers through games, conducting } \\
\text { business trainings, innovative model } \\
\text { of cooperation with farmers, going } \\
\text { beyond the industry with its own } \\
\text { bank for lending to farmers, selling } \\
\text { IT products for farmers }\end{array}$ & $\begin{array}{l}\text { The management sees the future of } \\
\text { agricultural holdings in providing } \\
\text { related services for small and medium- } \\
\text { sized farmers who are more efficient } \\
\text { in working on the land and solving } \\
\text { local issues. Therefore, the company } \\
\text { cooperates with farmers in the supply } \\
\text { chain on a partnership basis: providing } \\
\text { them with grain, fertilizers, access to } \\
\text { finance and helping with exports. It also } \\
\text { sells IT products for farmers: Smart } \\
\text { Agri for business process planning } \\
\text { and AP Agronomist for resource } \\
\text { management and field work. }\end{array}$ \\
\hline \multicolumn{4}{|c|}{ BANKING } \\
\hline $\begin{array}{l}\text { PrivatBank, } \\
\text { 83, net worth, } \\
01.01 .2019 \text { p.: } \\
282 \text { billion UAN }\end{array}$ & $\begin{array}{l}\text { The largest bank in the country, whose } \\
\text { services in } 2019 \text { were used by } 55.3 \% \text { of } \\
\text { the population of Ukraine for over } 16 \\
\text { years. The Privat } 24 \text { service has almost } 10 \\
\text { million users. According to the British } \\
\text { The Banker, PrivatBank is among the top } \\
10 \text { successful financial institutions in the } \\
\text { world. In the first nine months of } 2019 \text {, } \\
\text { the bank increased its income to UAH } \\
27.4 \text { billion. }\end{array}$ & $\begin{array}{l}\text { In 2019, PrivatBank showed } \\
\text { an ATM with face recognition, } \\
\text { introduced an updated application } \\
\text { Privat } 24 \text { with the function of } \\
\text { personalization of the interface, } \\
\text { the first in the world launched a } \\
\text { unique card design through the } \\
\text { application, one of the first in the } \\
\text { region - biometric payment using } \\
\text { face recognition FacePay } 24\end{array}$ & $\begin{array}{l}\text { By the end of the year, the bank plans } \\
\text { to introduce passive biometrics. } \\
\text { Together with MasterCard launched } \\
\text { a pilot project "cashless village" in the } \\
\text { village. Voloska, is working on business } \\
\text { solutions. PrivatBank has the largest } \\
\text { IT department among the country's } \\
\text { banks, and the function of internal } \\
\text { innovations is transferred to a separate } \\
\text { unit. }\end{array}$ \\
\hline \multicolumn{4}{|c|}{ ENERGY } \\
\hline $\begin{array}{l}\text { DTEK, } 73 \text {, net } \\
\text { profit, } 2018 \\
.: 51,2 \text { billion } \\
\text { UAN }\end{array}$ & $\begin{array}{l}\text { The largest energy holding in Ukraine. } \\
\text { In } 2018 \text {, net income amounted to } \\
\text { UAH } 51.2 \text { billion. The structure } \\
\text { includes enterprises for coal and gas } \\
\text { production, as well as production and } \\
\text { sale of electricity. Coal importer and the } \\
\text { leader in the number of green energy } \\
\text { companies in Ukraine }\end{array}$ & $\begin{array}{l}\text { Launched the first innovation hub } \\
\text { and training program for employees } \\
\text { to work with innovations. }\end{array}$ & $\begin{array}{l}\text { In 2018, DTEK invested about UAH } \\
20 \text { billion in the modernization of its } \\
\text { enterprises. The company also invests } \\
\text { in green energy and innovation, } \\
\text { some of which it initiates on its own } \\
\text { and some of which it receives from } \\
\text { technology teams around the world. } \\
\text { In Ukraine, it searches for innovations } \\
\text { using the Re:actor platform, as well as } \\
\text { the accelerator of energy startups based } \\
\text { on Radar Tech. }\end{array}$ \\
\hline \multicolumn{4}{|c|}{ TELECOM } \\
\hline $\begin{array}{l}\text { Kyivstar, } 75 \text {, } \\
\text { net profit, } 2018 \\
.: 18,7 \text { billion } \\
\text { UAN }\end{array}$ & $\begin{array}{l}\text { The largest mobile operator in Ukraine } \\
\text { ( } 26 \text { million subscribers) is also in the } \\
\text { top } 3 \text { in terms of the number of fixed } \\
\text { internet subscribers (about } 1 \text { million). } \\
\text { In addition, it provides digital television } \\
\text { services (up to } 147 \text { channels) and } \\
\text { financial services through its subsidiary } \\
\text { Smart Money. } \\
\text { Both the subscriber base of users and } \\
\text { the volume of traffic consumption are } \\
\text { growing. }\end{array}$ & $\begin{array}{l}\text { BigData analytics, financial services, } \\
\text { business solutions. Kyivstar's Big } \\
\text { Data solutions are used in the } \\
\text { analysis of transport flows of cities } \\
\text { and airports, as well as long- } \\
\text { distance communication, scoring } \\
\text { of microfinance organizations, } \\
\text { development of retail networks } \\
\text { and banks, etc. Kyivstar runs an } \\
\text { accelerator program for Radar Tech } \\
\text { startups. }\end{array}$ & $\begin{array}{l}\text { For private users, the operator develops } \\
\text { the direction of financial and content } \\
\text { services. For business - such services } \\
\text { as electronic document management, } \\
\text { CRM-system, MobileID, M2M and } \\
\text { IoT-connection, virtual PBX and } \\
\text { others. Since 2015, the company } \\
\text { has been developing Big Data, } \\
\text { cooperating with the state, business } \\
\text { and international donors, and training } \\
\text { specialists at Big Data School. }\end{array}$ \\
\hline
\end{tabular}


(End of Table 1)

\begin{tabular}{|c|c|c|c|}
\hline $\begin{array}{l}\text { Name } \\
\text { of the company, } \\
\text { vote threshold }\end{array}$ & Characteristic of company's activity & Main innovation & $\begin{array}{l}\text { Evaluation of the innovation regarding } \\
\text { the future }\end{array}$ \\
\hline \multicolumn{4}{|c|}{ TRANSPORT AND LOGISTICS } \\
\hline $\begin{array}{l}\text { Nova Poshta, } 76 \text {, } \\
\text { net profit, } 2018 . \text { : } \\
10,8 \text { billion } \\
\text { UAN }\end{array}$ & $\begin{array}{l}\text { The largest private logistics operator in } \\
\text { Ukraine by the number of branches, now } \\
\text { more than 5,000. Last year, Nova Poshta } \\
\text { processed } 174 \text { million items, which is } \\
\text { almost } 20 \% \text { more than in } 2017 \text {. As of } \\
\text { October } 2019 \text {, the mobile application of } \\
\text { NP has more than } 5 \text { million downloads }\end{array}$ & $\begin{array}{l}\text { Launch of innovative terminals } \\
\text { for mail processing, launch of } \\
\text { international delivery NP Shopping, } \\
\text { going beyond the industry - } \\
\text { financial services. }\end{array}$ & $\begin{array}{l}\text { Last year, NP opened a new automated } \\
\text { sorting terminal in Kyiv. And in the } \\
\text { spring of this year - a similar object in } \\
\text { the Khmelnytsky region. The company } \\
\text { intends to build similar sorting centers } \\
\text { in Kharkiv, Lviv and Dnipro. } \\
\text { In addition to IT solutions and } \\
\text { production automation, the company } \\
\text { implements a number of social and } \\
\text { environmental projects. For example, } \\
\text { since 2014, the Humanitarian } \\
\text { Post has been delivering goods to } \\
\text { volunteers, introducing the collection } \\
\text { of recyclables in its branches and } \\
\text { terminals. From April } 2019, \text { the state } \\
\text { of emergency is gradually moving to a } \\
\text { new type of packaging: instead of foam, } \\
\text { they began to use recycled paper. }\end{array}$ \\
\hline
\end{tabular}

Source: made by the author according to: (Mind Innovation Index, 2019)

a rational scheme of leadership and professionalism, optimization of the interaction of financial and material flows. The defining personal qualities of a professional leader should be: intelligence, ability to calculate the situation, and at the highest level - not so much to manage as to negotiate, ability to work in a team, reflexivity, responsibility for their own choice, sociability, mobility and more. In fact, the manager is no longer required to know either the production or the people employed in the production process. With only a rough idea of these things, he "manages" the contours of various economic relations. Thus, in the information society there should be a radical rethinking of the priorities and qualitative characteristics of a leader. And in this process the leading role should belong, in our opinion, to the development of leader's, specialist's transversal competencies.

Therefore, it is necessary to focus on the formation of intellectual potential of specialists of innovative business structures, because they will in the future form and ensure innovation-friendly regulation of companies.

Modern technoscience, as well as humanitarian technologies focused on human transformation and empowerment, are becoming the engine of economic growth through the introduction of interdisciplinary researches. This is how specific outsourcing is formed - a new way of life, new habits, needs, interests, values appear, i.e. the very social environment of a person changes; the volume and number of services / responsibilities (caring for animals, raising children, repairing an accomodation, a vehicle, household appliances, etc.) that he transfers to others, increases. All this causes a person to change and reorient their basic skills and abilities.

Thus, with the change of ontological, economic, political components in society, others also change (epistemological, ideological, axiological, etc.). And one of the leading roles in this, in our opinion, should belong to LLL-education. Now there is an urgent need to change the priorities of the education sector in order to train a specialist whose knowledge will not be limited only once and for all by hard skills in the field of formalized technologies (finance, auditing, logistics, marketing, etc.) to be able to perceive changes, influence them, as well as to change oneself, i.e. to acquire new skills and abilities - soft skills, less formalized, necessary in any profession (table 2).

The marketing and management system, constantly changing quantitatively and qualitatively, forms a demand for qualitative (against the background of reducing quantitative, including staff reductions) staffing indicators for all specialties (new requirements for soft skills).

In order to determine which skills are relevant in today's society, Microsoft (2013) conducted a study of the required competencies for the TOP- 60 highest paid professions that contribute to the creation of new value of professionals (Figure 1).

At the top of the list of the top 60 highest paid professions were public speaking and communication skills, computer competence and a high level of selforganization.

The British e-learning platform SkillsYouNeed complements them with personal skills (time 
Table 2

Comparative table Hard Skills and Soft Skills

\begin{tabular}{|l|l|}
\hline \multicolumn{1}{|c|}{ Hard Skills } & \multicolumn{1}{|c|}{ Soft Skills } \\
\hline Highly specialized competencies & Interprofessioan, universal competencies \\
\hline $\begin{array}{l}\text { Expertise - operate within a specific profession, sustainable } \\
\text { conditions and a formalized work process }\end{array}$ & Values - useful for any activity \\
\hline Technical knowledge, qualification & Behavioral pattern relevant to actions \\
\hline Critical in the short term & Critical in the long run \\
\hline $\begin{array}{l}\text { Development is faster, effective for solving typical problems } \\
\text { specific to one area of activity }\end{array}$ & $\begin{array}{l}\text { Development is slower,it is allowed to adapt to new conditions quickly, } \\
\text { change the field of employment, solve non-standard problems }\end{array}$ \\
\hline $\begin{array}{l}\text { Implementation with less effort and guaranteed results (subject } \\
\text { to compliance with basic criteria: motivation, ability to learn, etc.) }\end{array}$ & $\begin{array}{l}\text { Implementation with great effort, achieving the required level is } \\
\text { not guaranteed ("limit" of competencies, deep integration into the } \\
\text { personality structure, etc.) }\end{array}$ \\
\hline Virtually not prone to reversal & In specific conditions - prone to reversal development \\
\hline
\end{tabular}

management, self-development, emotion management and even nutrition, body care, sports training, effective sleep) and interpersonal skills (communication, teamwork, negotiation, conflict management).

Forbes believes that interpersonal skills are the most important, it adds creativity, ability to work in a team and ability to "re-engineering" - willingness to do familiar things in a new way, i.e. ability to constructive interpersonal interactions.

Business skills are integrated into soft skills in the modern world, they accumulate knowledge of intellectual property, investment and financial literacy,

Oral and written communication skills*

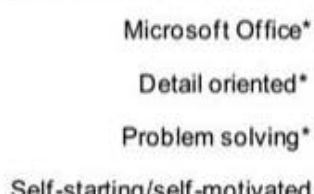

Self-starting/self-motivated
Organizational skills*

Work independently

Microsoft PowerPoint*

Project management*

Sales experience

Troubleshooting

Customer service oriented

Time management

Business development

Analytical skills*

Microsoft Word*

Bilingual/multilingual*

Strong interpersonal skills*

Work ethics

Linux

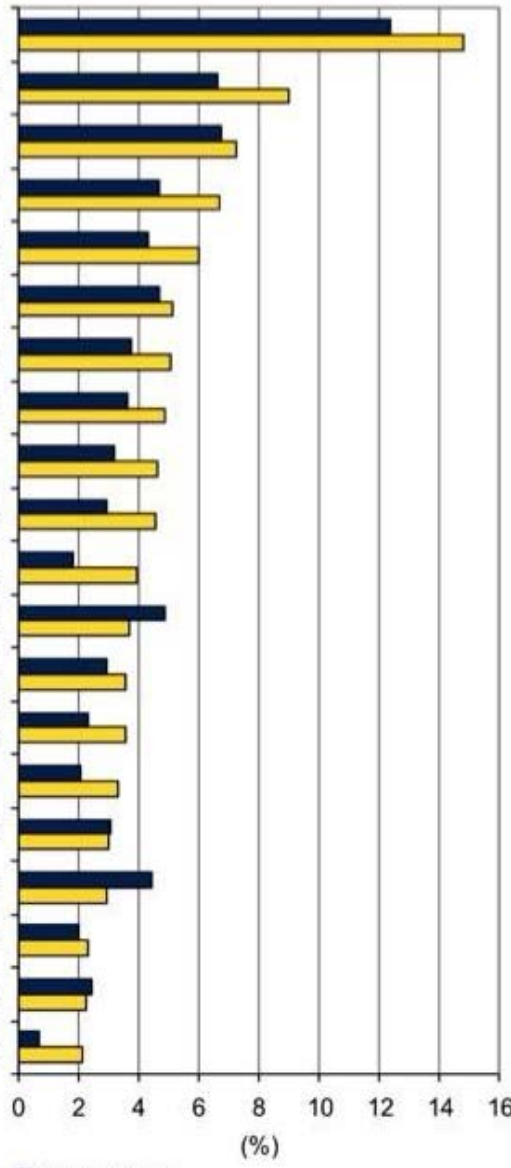

-All positions

마igh-growth/high-wage positions

Figure 1. IDC Study: Top Skills Comparison 2013

Source: Indicates Communication, Integration, or Presentation skill; Source: IDC, based on Wanted Analytics and U.S. Bureau of Labor Statistics Data, October 2013 
sales skills, presentations and business negotiations, event management, project management, people, their work and time and more.

The ability to work in a team, reflexivity, responsibility for one's own choice, sociability, mobility are the transversal competencies that, in our opinion, should be formed by the new educational paradigm through the introduction of interdisciplinary research. They also include leadership, critical thinking, reflective thinking, creativity, the ability to take responsibility and work in critical conditions, communication skills, cooperation. Communication, inter- and intrapersonal skills should be dominated by teamwork, collegiality, adjusting conflicts, ability to compromise, empathy, time management, self-discipline, self-esteem, abikity to overcome a crisis, emotion and stress modulation, understanding the importance of deadlines, etc.

Thus, in a globalized world, the mere ability to produce something is not enough, the main factor is the ability to increase the value of goods and work for the success of the company. Apparently, there is a shift towards the increasing importance of branches which Lester Thurow calls "brain" (Thurow, 1996) - biotechnology, media and computer programming, as they are the only reliable bet in the global economic game. Cheap labor, which is abundant in the world, without these branches is not able to produce new complex products, in addition, these products can be cheaper than now, because when the product is already developed, the cost of its production becomes minimal.

As a result, the professions related to operations and management, especially marketing and management, become a priority. Specialists in these fields are able to provide additional value for products and services through global networks, creative skills, financial insight and effective advertising. Representatives of these professions work in conditions of constant change, and their main feature is flexibility, the ability to adapt to countless new situations. Thanks to mainly LLL-education and interdisciplinary research, the information worker always has the ability to re-certify himself, he is sensitive to the latest challenges in his field, closely monitors market fluctuations, changes in public sentiment, and therefore can always improve the product. A modern marketer or manager does not want to keep a permanent position in a solid corporate bureaucracy, but prefers to move from project to project, concluding short-term consulting contracts and constantly updating their knowledge to effectively solve a certain task. He creates his own career, his own "portfolio", and does not take it from the hands of the corporate bureaucracy (Handy, 1995).

The tendency to subject-subject integrations of transversal competencies into education is being actualized due to the introduction of a new educational paradigm of LLL-education. If an employee has previously mastered a set of techniques once and for all, in the information society he must be constantly ready to acquire new skills and abilities as new (or programmed) technologies and interdisciplinary research are introduced. This "breadth of skills" (Block, 1990) means that a worker will grow professionally throughout life, using the opportunities for retraining, reskilling and changing the types of work in the modern production space.

Alvin Toffler presented an analysis of the process of global socio-economic development in the concept of the "Third Wave" (Toffler, 2000) (Table 3).

Post-industrial society is a society dominated by an innovative sector of the economy with a highly productive industry, knowledge industry, high share in GDP of high quality and innovative services, competition in all economic and other activities, as well as a higher share of the population employed in services than in industrial production. Knowledge and the availability of information have become the symbolic capitals that determine the place of every society in the world system. The United States and Western Europe have crossed the line where the main factor in economic prosperity is no longer material production or even the market for services, but the market for information. The emergence of new science-intensive technology, reorganization of production on the basis of introduction of the latest advances in science and technology have set in motion the "third wave" of civilization. Therefore, the personality of the future cannot be depicted in terms of the previous civilization, because it is a revolution in the whole inner world of man, which will affect his consciousness and subconscious.

The conclusion of the report "The Future of Jobs" (2016) of the World Economic Forum (WEF) in Davos states that the Fourth Industrial Revolution,

Table 3

Civilizational changes are characteristic of the three waves (according to E. Toffler)

\begin{tabular}{|c|c|c|c|}
\hline Spheres & First wave & Second wave & Third wave \\
\hline Type of civilization & agrarian & industrial & superindustrial \\
\hline \multirow{2}{*}{ Family } & big & small & мала \\
\hline & patriarchal & nuclear & nonnuclear \\
\hline Education & In family, individual & Factory type, mass & Inforsphere, demasified \\
\hline Trade & on a by-order basis & mass & mass on a by-order basis \\
\hline Employment & agricultural & factory, office & electronic college \\
\hline Mass media & local & mass & demassification of mass media information \\
\hline
\end{tabular}


which includes developments in previously untapped areas such as artificial intelligence and mechanical engineering, robotics, nanotechnology, 3-D printing and genetics, biotechnology, will change and update not only business models but also labor markets over the next five years. The emergence of new professions is forecasted: 3D-designers; neuroimplantation technicians, specialists in neurorobotology engineering; consultants on improving cognitive abilities, ethics of genetic modification, digital detectives, defenders of confidentiality, compilers of technological laws, etc.

Exploring the modern world order and digital technologies, Nobel Peace Prize winner and international relations expert Henry Alfred Kissinger put forward the idea of an old order that is constantly changing herewith the form, that is intended to replace it, is still uncertain. (Kissinger, 2015). Another researcher, Emanuel Fress, a digital business and social media consultant, notes that the digital age is an age "where there are no boundaries, but there is a collaborative approach to problem solving, global business vision, speed as a key to success, the process of continuous testing. and education ... "(Fress, 2014) throughout a person's life.

\section{Creation and development of knowledge economy}

As the managerial attitude acquires the features of a purely technological, turning into programming: manual $\rightarrow$ computer $\rightarrow$ machine, there is a new interdisciplinary phenomenon - "information management" as " a new era in management" impersonal post / non / management, and we lack no knowledge, but the will to perform, the power to selfgovernment (Kutyrev, 2009). Therefore, we will try to analyze the creation of a management system that is reduced to a purely technological programming. It proves to be effective in terms of methods and fruitful in terms of results, aimed at training a new generation of staff and creating a basis for tactics of impersonal post / non / management.

There is a transition to a new economy - knowledge economy, where the determinants are due to interdisciplinary research on the accumulation and use of information and its transformation into knowledge, which, along with labor, finance and natural resources, depends on economic progress. Knowledge economy is based on the intellectual potential of society, which is a set of scientific and everyday knowledge embodied in technology, culture, production, environment and everyday life through the nomadic practices of LLL-education.

In the book "Shock of the Future" (Toffler, 2000), Alvin Toffler defined the structure of technological innovation, which consists of 3 stages: 1 ) a creative idea that can be implemented; 2) traditional and innovative practice; 3 ) distribution in society (marketing practices).
The main thing is that the introduced innovations must be accepted by the society. They allow completely new ways of solving social, philosophical, economic, political and even personal and interpersonal problems and change everything intellectually: human environment and its worldview, cognitive abilities, value system, needs and interests and more. According to the futurist, if technology is considered as a large engine, a powerful accelerator, then information and knowledge should be considered as its fuel. Education from the system (one for all) turns into an educational network (all for all). The main thought - for creators of ideas, practitioners, marketers and managers need mostly LLL-education in the formation of intellectual potential. In order to be successful in the professional sphere in the context of global change, it is necessary to have different competencies. It is sustainable development and economic competitiveness in the process of lifelong learning which focus on the formation of professionals' intellectual potential, the development of interpersonal skills (Tolochko, 2016).

This should be useful for the creation and development of knowledge economy through finding and implementation of synchronicities in all scientific fields:

scientific and educational clusters (cluster formations that unite research institutions and educational establishments with a strong scientific and educational base and a high level of intellectual potential) that are able to produce, push forward and promote practical implementation and dissemination of innovations; to solve complex socio-economic, technical and other problems at the request of authorities and business structures; develop relationships and cooperate with existing enterprises in order to create bases for production practice and testing the results of research (Pyatnytska, 2015). The key task is: training and retraining of qualified personnel in accordance with the needs of the world market through the introduction of continuing LLL-education;

crowd technologies designed to rediscover the process of communication: on the one hand, the subject is affected by information that arises, is formed and runs through the network, on the other - a subject in a virtual environment interacts with other subjects (mobile, or users), forming communities (pulsating organizations (Iliashenko, 2016), and objects (mobile devices), forming Homomobilis, or cyberphysical systems (Melnyk, 2016)) (without human intervention / involvement) Kateryna Poltorak suggests using a twotier communication model from the traditional "one-tomany communication model" to the innovative "manyto-many communication model” (Poltorak, 2015);

crowdsourcing as a process of transferring certain production functions to an indefinite circle of people (the term was first coined by writer Jeff Howie and "Wired" editor Mark Robinson (2006).) Amateurs 
gained an additional market to reveal their abilities, and businesses gained ways to use hidden talent of a crowd. This is free or low-paid work, which adds to the efficiency of full-time employees. It's not outsourcing, it's crowdsourcing "(Howe, 2006), it's a part of what American economist Eric von Hippel calls "user-centric innovation". Innovations are fast becoming democratic. With the advancement of computer and communication technologies, users are increasingly able to develop their own new products and services. Innovations of users - both individuals and companies - often become open and freely available, which initiates the creation of information communities and a lot of intellectual property (Hippel, 2005). This technology has not only a number of advantages (interacting with the manufacturer, a consumer receives a product created to his wishes, but also feels involved in the brand; huge free marketing research and advertising; crowd psychology works for the benefit of a manufacturer: a crowd does the work - a manufacturer makes a profit) and a number of disadvantages and limitations: involvement of a wide range of participants involves the loss of their own time and effort to participate in public discussion of the problem, generating ideas and proposals, which raises the question of motivation of project participants; in the process of public search for innovations it is necessary to provide for the allocation of resources and identify methods to solve the problem of the need for highquality analytical processing of incoming proposals.

LLL education has to spread these ideas. According to the concept of American analysts, currently only a few countries are in transit and are able in the next 15-20 years to move from five to six technology mode. As for Ukraine, it is between the fourth and fifth mode. The structure of our country's economy is a symbiosis of industrial and post-industrial sectors of the economy. Ukraine has significant achievements in the military and space spheres, develops such industries as nano- and biotechnology, but the main export product remains metallurgy and chemical products. It should be noted that compared to our western neighbours, Ukraine is technologically higher, as Poland, Hungary, Slovakia, and the Czech Republic are just taking the first steps to move from the era of industrialism to the era of "knowledge and information technology." The main thing, as pointed out by E. Toffler (Toffler, 2002), is to prepare the country for a big leap, as well as to reduce the negative consequences of facing the "shock of the future".

\section{Conclusions}

An analysis of international experience in the creation of innovative business structures - from companies "gazelles" to clusters that play a leading role in economic development. However, Ukraine is in a transitional stage of development, characterized by the growing role of trends uncontrolled by people, that motivate them to social changes in all areas, including economy. The main large companies in various sectors of economy are characterized by the innovation index.

Two approaches to the management of business structures are analyzed. The first is based on the implementation of subject-subject relationships, the development of innovative transversal competencies in order to expand managers' breadth of "management skills" through LLL-education. The second is the experience of innovative enterprises, where management is transformed into information management with its inherent impersonal post / non / management.

Formation of transversal specialists' of innovative business structures competencies is provided by changes in hard skills, acquisition of new soft skills and integrated business skills, which contributes to the creation of a new generation of specialists. It is determined that the intellectual potential of society is a set of scientific and everyday knowledge embodied in technology, culture, production, everyday life, the environment and so on.

It is important to move to a new economy - the knowledge economy, which is based on the intellectual potential of society, in which the main levers are the processes of accumulation and use of information and its transformation into knowledge, which influense economic progress. The development of knowledge economy is based on formation of scientific and educational clusters, introduction of crowdfunding technologies, crowdsourcing in lifelong learning, which provides professional development of specialists in innovative business structures.

For the effective development of Ukraine, it is necessary to conduct research on innovative entrepreneurial activity in the country, implement cluster policy and start training specialistsentrepreneurs, taking into account the experience of other countries on the basis of LLL-education.

\section{References:}

Accommodating Soft Skills in Software Project Management. Retrieved from: https://www.researchgate.net/ publication/320655984_Accommodating_Soft_Skills_in_Software_Project_Management

Birch, D. L. (1979). The Job Generation Process: a Report, prepared by the Massachusets Institute of technology Program on Neighbourhood and Regional change for the Economic Development Administration. US Department of Commerce. Washington-Cambridge. Mass: MIT, Press.

Block, F. (1990). Postindustrial Possibilities: A Critique of Economic Discourse. Berkley, CA: University of California Press. 
Iliashenko, S. M., \& Iliashenko, N. S. (2016). Prospects and threats of the fourth industrial revolution and their consideration in the choice of strategies for innovative growth. Marketing and innovation management, no. 1, pp. 11-21.

Fress, E., Erblang-Rotaru, I., \& Michelin, A. (2014). All about ... Business is digital Now! Catch the moment! 169 p. (Project business is digital.com). Retrieved from: http://flibusta.website/b /427331/read

Handy, C. (1995). The Age of Unreason. Arrow.

Hippel, Eric von. (2005). Democratizing Innovation (The MIT Press. Cambridge, Massachusetts. London, England). Retrieved from: http://web.mit.edu/evhippel/www/democ1.htm

Howe, J. (2006). The Rise of Crowdsourcing. WIRED. Retrieved from: https://www.wired.com/2006/06/ crowds/

Knysh, I. V. (2018). Conceptualization of nomadism: sociocultural discourse: monograph. Odessa: Kuprienko S. V. Knysh, I. V. (2018). Management upgrade in the context of complexity. Practical philosophy. Kyiv: Ed.: Parapan, no. 1(67), pp. 46-55.

Hubanov, O., Mosondz S., \& Melnychuk O. (2018). Transformational dimensions of science under globalization challenges. Baltic Journal of Economic Studies, vol. 4, no. 5, p. 59-62. doi: 10.30525/2256-0742/2018-4-5-59-62

Kaplinsky, R. (1983). Firm Size and Technical Change in a Dynamic Context. The Journal of Industrial Economics, vol. 32, no. 1, pp. 39-59.

Kirchhoff, B. A. (1994). Entrepreneurship and Dynamic Capitalism: The Economics of Business Firm Formation and Growth (Praeger Studies in American Industry). Praeger, Westport, CT. 240 p. Retrieved from: https://books.google. com.ua/books?id=_aVSzzMOUTEC\&pg=PA1\&hl=ru\&source=gbs_toc_r\&redir_esc=y\#v=onepage\&q\&f=true

Kissinger, H. (2015). World order. London: Penguin Books.

Mind Innovation Index 2019: artificial intelligence, but pirated software (2019). Retrieved from: https://mind.ua/ publications/20203121-mind-innovation-index-2019-shtuchnij-intelekt-ale-piratskij-soft

Melnik, L. G. (2016). Innovative prospects of the third industrial revolution: economy, energy, ecology. Marketing and Innovation Management, no. 4. Retrieved from: http://mmi.fem.sumdu.edu.ua/sites/default/files/ mmi2016_4_342_352.pdf

Kutyrev, V. A. (2009). Genesis or. SPb.: Aleteya Publishing House.

New study reveals most important skills for students. REDMOND, Wash. Oct. 15, 2013. Retrieved from: https://news.microsoft.com/2013/10/15/new-study-reveals-most-important-skills-for-students/

Poltorak, K. A. (2015). Management of marketing communications in the era of crowd technologies. Marketing and innovation management, no. 3, pp. 66-75.

Piatnytska, H. T. (2015). Classification of clusters in the system of information support of clustering strategy. Marketing and innovation management, no. 4, pp. 187-208. Retrieved from: http://mmi.fem.sumdu.edu.ua/sites/ default/files/mmi2015_4_187_208.pdf

Soete, L. (1979). Firm Size and Innovative Activity: The Evidence Reconsidered. European Economic Review, vol. 12, pp. 319-340.

Toffler, A. (2002). Shock of the future: translated from English. Edited by Gurevich P.S. Moscow: ACT Publishing House LLC.

Toffler, A. (2000). Third Wave / translated from English. .Evsa A. Kyiv: Ed. house "Universe".

Thurow, L. (1996). The Future of Capitalism / Lester Carl Thurow, Nicolas Brealey. New York: Penguin Books.

The Future of Jobs. Employment, Skills and Workforce Strategy for the Fourth Industrial Revolution. Retrieved from: http://www3.weforum.org/docs/WEF__Future_of_Jobs.pdf

Tolochko, S. (2016). Economi competitiveness and modern pedagogics definitions correlation. Baltic Journal of Economic Studies, vol. 2, no. 1, pp. 101-106. doi: 10.30525/2256-0742/2016-2-1-101-106

Voitovska, O., Tolochko, S., \& Bordyug, N. (2018). Lifelong Learning in Modern Strategies of Sustainable Development. Studia warmińskie, no. 55, pp. 343-353.

Voitovska, O., \& Tolochko, S. (2019). Lifelong Learning as the Future Human Need. International Society of Philosophy and Cosmology (ISPC), vol. 22, pp. 144-151. 